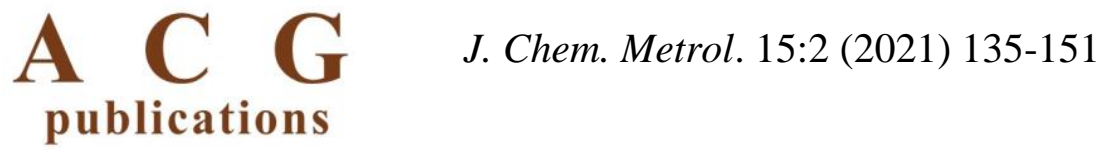

journal of chemical metrology

\title{
LC-HRMS profiling of phytochemicals, antidiabetic, anticholinergic and antioxidant activities of evaporated ethanol extract of Astragalus brachycalyx Fischer
}

\section{Hatice Kızıltaş $\oplus^{1}$, Zeynebe Bingöl $\oplus^{2,3}$, Ahmet C. Gören $\oplus^{4,5^{*}}$, Suleyman Mesut Pinar ${ }^{\circ}$, , Saleh H. Alwasel ${ }^{7}$ and İlhami Gülçin ${ }^{\circ}$ 3,*}

\author{
${ }^{1}$ Vocational School of Health Services, Van Yuzuncu Yil University, 65080-Van, Türkiye \\ ${ }^{2}$ Vocational School of Health Services, Tokat Gaziosmanpasa University, Tokat, Türkiye \\ ${ }^{3}$ Department of Chemistry, Faculty of Sciences, Atatürk University, 25240-Erzurum, Türkiye \\ ${ }^{4}$ Department of Chemistry, Faculty of Basic Science, Gebze Technical University, 41400-Gebze- \\ Kocaeli, Türkiye \\ ${ }^{5}$ Drug Application and Research Center (ILMER), Bezmialem Vakif University, 34093, \\ Fatih-İstanbul, Türkiye \\ ${ }^{6}$ Van School of Health, Yüzüncü Yll University, 65090-Van, Türkiye \\ ${ }^{7}$ Department of Zoology, College of Science, King Saud University, Riyadh, Saudi Arabia
}

(Received July 30, 2021; Revised August 22, 2021; Accepted August 25, 2021)

\begin{abstract}
Astragalus is a perennial plant that has existed for about 2500-3000 years and consists of more than 250 taxonomic parts. Twenty species of Astragalus are endemic to Turkey, as well as the richest genus with 425 taxa. The roots of Astragalus species are used in folk medicine as hepatoprotective, antioxidant, antibacterial, antihypertensive, antidiabetic and diuretic. Also, it is used to treat diabetes mellitus, leukemia, nephritis and uterine cancer. It is known that in Anatolia, Astragalus roots are traditionally used against leukemia and wound healing. For the purpose, the measuring of antioxidant activity of evaporated ethanol extract of Astragalus brachycalyx FISCHER (EEAB), some bioanalytic methods including DPPH ${ }^{*}$ and $\mathrm{ABTS}^{++}$scavenging effects, ferric ions $\left(\mathrm{Fe}^{3+}\right)$ and cupric ions $\left(\mathrm{Cu}^{2+}\right)$ reducing abilities, and metal $\left(\mathrm{Fe}^{2+}\right)$ chelating activity were realized. $\alpha$-Tocopherol, ascorbic acid, and BHT were used as the standard antioxidants. On the other hand, some phenolic compounds, which responsible for antioxidant activities of EEAB was determined by liquid chromatography-high resolution mass spectrometry (LC-HRMS). At the similar concentration, EEAB exhibited efficient antioxidant effects when compared to standard compounds. Additionally, EEAB showed $\mathrm{IC}_{50}$ values of $1.985 \mu \mathrm{g} / \mathrm{mL}$ toward acetylcholinesterase (AChE), $0.620 \mu \mathrm{g} / \mathrm{mL}$ on $\alpha$-glycosidase and $0.306 \mu \mathrm{g} / \mathrm{mL}$ against $\alpha$-amylase enzymes.
\end{abstract}

Keywords: Astragalus brachycalyx; phenolic compounds; antioxidant activity; acetylcholinesterase; $\alpha$ glycosidase; $\alpha$-amylase. @ 2021 ACG Publications. All rights reserved.

\footnotetext{
*Corresponding author: E-Mail: igulcin@atauni.edu.tr (İ. Gulcin) ; Phone: +90442 2314375, Fax :+90442 2314109; acgoren@gtu.edu.tr (A.C. Goren).
} 


\section{Introduction}

Astragalus L., which belongs to the Fabaceae family, is locally called as "geven". Astragalus L. is a perennial herb that has existed for about 2500-3000 years and consists of more than 250 taxonomic parts [1]. Twenty species of Astragalus L. are endemic to Turkey, as well as the richest genus with 425 taxa [2]. Plants of this genus are used in scientific or folk medicine in many countries [3]. It is known that the roots of Astragalus species are used in folk medicine as hepatoprotective, antioxidant, antibacterial, antihypertensive, antidiabetic and diuretic. It is also used for treatment of diabetes mellitus, leukemia, uterine and nephritis cancers. In Anatolia, Astragalus roots are traditionally used for treatment of wound healing and leukemia [2]. These biological activities depend on the presence of various secondary metabolites of this plant [4]. In particular, phenolics, alkaloids, flavonoids, anthraquinones and saponins are thought to be the main chemicals responsible for its biological activities [5]. It has been reported that some bioactive compounds from Astragalus species had immunostimulant and anticancer activities [6].

Changing living conditions, environmental pollution, industrial wastes, sun rays, exhaust gases, heavy metals, cigarettes and various chemicals have become elements that today's people cannot escape [7,8]. All this causes the formation of reactive oxygen species (ROS) and free radicals, which have hazardous effects for living organisms [9-11]. Despite the increasing number of free radicals, the protective effect of antioxidant metabolism can often be insufficient [12-14]. Oxidative stress plays a crucial role in many diseases including cancer, Alzheimer's disease (AD) and type-2 diabetes mellitus (T2DM) [15-17]. On the other hand, antioxidants delay the formation of degenerative diseases due to free radicals and ROS formation by reducing oxidative stress in the body. These chemicals also had protective effect of body against metabolic disorders or damages caused by free radicals and ROS [1820]. Recently, the use of synthetic antioxidants like BHA and BHT has been restricted due to their undesired effects like carcinogenic effect. So, the studies on natural antioxidants are of great importance $[21,22]$.

Today, many plants are used both as medicine among the public in terms of the effective substances they contain and medical studies are carried out on them [23]. The fact that natural antioxidant vitamins such as $\beta$-carotene, $\alpha$-tocopherol, ascorbic acid are abundant among the active components that plants contain, makes these products of natural origin very important [24-26]. For this purpose, great importance has been recently attached for evaluation of medicinal plants as antioxidant sources in many related industrial fields, especially in medicine, food and cosmetics [27,28]. In addition, the use of drugs derived from medicinal plants and plant-based products is increasing significantly [15,29-31].

This study aimed to determine the antidiabetic, anticholinergic, antioxidant and radical scavenging activities of the evaporated ethanol extract (EEAB) of aerial parts of Astragalus brachycalyx. For this purpose, potassium ferricyanide reducing, $\mathrm{Fe}^{3+}{ }_{-}$TPTZ reduction (FRAP), copper ions $\left(\mathrm{Cu}^{2+}\right)$ reducing capacity (CUPRAC), $\mathrm{DPPH}^{-}$and $\mathrm{ABTS}^{-+}$scavenging and metal chelating experiments were used. Total phenolic contents in EEAB were quantitatively determined by liquid chromatography and high resolution mass spectrometry (LC-HRMS), in addition, total phenolic and flavonoid contents were determined. Another aim of this study was identified the possible inhibitory effects of EEAB toward acetylcholinesterase, $\alpha$-amylase and $\alpha$-glycosidase enzymes. It is aimed that our study will be a reference for future studies.

\section{Materials and Methods}

\subsection{Chemicals}

The compounds, which are used for determination of antioxidant activity including 2,2-azino-bis3-ethylbenzthiazoline-6-sulfonic acid (ABTS), 3-(2-pyridyl)-5,6-bis (4-phenyl-sulfonic acid)-1,2,4triazine (Ferrozine), neocuproine (2,9-dimethyl-1,10-phenanthroline), 1,1-diphenyl-2-picryl-hydrazyl (DPPH), butylated hydroxytoluene (BHT), trichloroacetic acid (TCA), $\alpha$-tocopherol and ascorbic acid, standard phenolics compounds for LC-HRMS were obtained from Sigma (Sigma-Aldrich GmbH, 
LC-HRMS profile of Astragalus brachycalyx extracts and theirbiological activities

Steinheim, Germany). The other compounds used were of analytical grade and purchased from either Sigma-Aldrich or Merck Millipore.

\subsection{Plant Material}

Astragalus brachycalyx FISCHER was collected from Bitlis in July 2019 (Location: $38^{\circ} 24^{\prime 2} 21.2^{\prime \prime} \mathrm{N} 42^{\circ} 06^{\prime} 04.2^{\prime \prime E}, \mathrm{MP} 16561$ code). This Astragalus species was identified by botanist Dr. Süleyman Mesut PINAR, Department of Nutrition and Dietetics, Faculty of Health Sciences, Van Yüzüncü Y1l University. Plant samples were deposited at Herbarium of the Biology Department (VANF), Faculty of Science, Van Yüzüncü Y1l University, Van, Turkey.

\subsection{Evaporated Ethanolic Extract (EEAB)}

The extraction procedure was applied as described formerly $[32,33]$. To prepare the EEAB, first $50 \mathrm{~g}$ of the plant material was ground to powder and soaked in $0.5 \mathrm{~L}$ ethanol then the solvent was evaporated using a rotary evaporator (Heidolph Hei-VAP HL, Germany) [34]. Plant extract which obtained in dry form is stored at $-20^{\circ} \mathrm{C}$ until used.

\subsection{Total Phenolics and Flavonoids Contents}

To determine the total phenolic contents of EEAB, a previous method was used [35]. Gallic acid (GA) was used as standard phenolic. Total phenolic content in EEAB was determined as GA equivalent (GAE) [36]. The total flavonoids in EEAB carried out as described previously [37]. Quercetin (Q) was used as standard flavonoid. The quantity of total flavonoid was determined as microgram $Q$ equivalent (QE) from the equation obtained from the standard quercetin plot.

\subsection{Reducing Ability Assays}

The $\mathrm{Fe}^{3+}$ reducing ability of EEAB was carry out by the $\mathrm{Fe}^{3+}(\mathrm{CN}-)_{6}$ reducing procedure [38-42]. For determination of copper ions $\left(\mathrm{Cu}^{2+}\right)$ reduction capacity of EEAB, the method of Apak et al. was applied with some modification [43,44]. The FRAP reducing method was realized based on spectrophotometric measurement of reduction of TPTZ- $\mathrm{Fe}^{3+}$ complex under acidic conditions [45-47].

\subsection{Metal Chelating Ability}

Metal chelators prevent oxidation by reducing the activity of metals such as iron after complex formation. Metal chelating capacity of EEAB was measured according to the disruption of $\mathrm{Fe}^{2+}-$ ferrozine complex with some modifications $[48,49]$.

\subsection{Radical Scavenging Ability}

$\mathrm{DPPH} \cdot$ scavenging ability of EEAB was determined according to Blois method [50] as given previously [51,52]. Different concentrations $(25-75 \mu \mathrm{g} / \mu \mathrm{L})$ of EEAB were completed with ethanol and $1 \mathrm{~mL} \mathrm{DPPH} \cdot$ in test tubes and their absorbances were measured at $517 \mathrm{~nm}$. Another radical scavenging assay is $\mathrm{ABTS}^{+\bullet}$ scavenging effect and realized according to the previous study [53]. This method was used to define the $\mathrm{ABTS}^{+\bullet}$ scavenging efficacies of EEAB.

\subsection{Anticholinergic and Antidiabetic Assays}

The inhibition ability of EEAB on acetylcholinesterase (AChE) from Electric eel was realized according to previous studies [54-58]. To determine the $\alpha$-glycosidase inhibition of EEAB, the method, which described in previous researches was applied [58-60]. The $\alpha$-amylase inhibition efficacy of EEAB was estimated according to previous studies $[61,62]$. The $\mathrm{IC}_{50}$ was calculated from activity $(\%)$ versus of EEAB concentration plots [63-66]. 


\subsection{LC-HRMS Analysis}

Determination of phenolic content of EEAB was made according to LC-HRMS analysis method [67-69]. LC-HRMS experiments were performed on a Thermo ORBITRAP Q-EXACTIVE mass spectrometry equipped with a Troyasil C18 column ( $150 \times 3 \mathrm{~mm}$ i.d., $3 \mu \mathrm{m}$ particle size $)$ [70]. The finest mobile phase was determined in acidified methanol and water gradient by HPLC method [67,70-72]. The identification of phenolic compounds was made by comparing the retention times of the standard compounds (in the range of purity 95\%-99\% see section chemicals) and HRMS data of Bezmialem Vakıf University, Drug Application and Research Centre Library (ILMER). Dihydrocapsaicin (95\% purity) used as an internal standard for LC-HRMS measurements for reduce to repeatability problem of caused by external effects, such as ionization repeatability, in mass spectrometry measurements. 100 $\mathrm{mg} / \mathrm{L}$ dihydrocapsaicin (97\%, Sigma-Aldrich) solution was used as an internal standard (IS). The mass parameter of the target compounds is given in previous studies $[16,68,69]$.

\section{Results and Discussion}

In recent years, there has been a significant increase in studies investigating the biological activities of crude extracts or isolated pure compounds from plants. Natural products had a great importance in the drug development process for cancer and infectious diseases. Many species have been investigated in terms of their antioxidant activities and some species have been determined to have an important biological potential in these subjects [73-75]. Many Astragalus species have been examined for their antioxidant, antiviral, anticancer, cytotoxic, immunostimulant, analgesic, and antiinflammatory effects. Astragalus species have been reported to contain bioflavonoids, amino acids, triterpene glycosides, flavonoids, isoflavonoids, and saponins [76]. The antioxidant potential of Astragalus brachycalyx has been investigated in order to determine its health benefits and to be a step for further studies. For this intention, three metal reduction methods (FRAP, CUPRAC and $\mathrm{Fe}^{3+}$ reduction) and two radical removing assays (DPPH and ABTS scavenging) and $\mathrm{Fe}^{2+}$ chelating ability were applied for the EEAB. In this study, a combination of selected bioanalytical antioxidant methods was also performed to extract complementary information about antioxidant mechanisms. The antioxidant profile of ethanol extract obtained from aerial parts of Astragalus brachycalyx, as characterized using $\mathrm{Fe}^{3+}$ reducing, CUPRAC and $\mathrm{Fe}^{3+}$-TPTZ reducing (FRAP) assays, shown in Table 1 and Figure 1 .

Table 1. The reducing power of the EEAB and standards by $\mathrm{Fe}^{3+}$ reducing $(120 \mu \mathrm{g} / \mathrm{mL})$ and $\mathrm{Fe}^{3+}-\mathrm{TPTZ}$ reducing $(150 \mu \mathrm{g} / \mathrm{mL})$ and $\mathrm{Cu}^{2+}$ reducing $(30 \mu \mathrm{g} / \mathrm{mL})$ methods

\begin{tabular}{lcccccc}
\hline \multirow{2}{*}{ Antioxidants } & \multicolumn{2}{c}{$\mathbf{F e}^{\mathbf{3 +}}$ reducing } & \multicolumn{2}{c}{$\mathbf{C u}^{2+}$ reducing } & \multicolumn{2}{c}{$\mathbf{F e}^{\mathbf{3 +}}$-TPTZ reducing } \\
\cline { 2 - 7 } & $\boldsymbol{\lambda}_{\mathbf{7 0 0}}$ & $\mathbf{r}^{\mathbf{2}}$ & $\boldsymbol{\lambda}_{450}$ & $\mathbf{r}^{\mathbf{2}}$ & $\boldsymbol{\lambda}_{\mathbf{5 9 3}}$ & $\mathbf{r}^{\mathbf{2}}$ \\
\hline Ascorbic acid & $1.520 \pm 0.028$ & 0.9970 & $1.069 \pm 0.007$ & 0.9722 & $1.624 \pm 0.015$ & 0.9930 \\
$\boldsymbol{\alpha}$-Tocopherol & $0.990 \pm 0.007$ & 0.9942 & $0.785 \pm 0.061$ & 0.9986 & $0.755 \pm 0.075$ & 0.9867 \\
BHT & $1.269 \pm 0.005$ & 0.9880 & $1.561 \pm 0.089$ & 0.9978 & $0.909 \pm 0.006$ & 0.9874 \\
EEAB & $0.849 \pm 0.001$ & 0.9460 & $0.598 \pm 0.003$ & 0.9996 & $0.521 \pm 0.108$ & 0.9808 \\
\hline
\end{tabular}

Ferric reducing power is an important test for determination of antioxidant activity. It is widely used for investigation of antioxidant activities of natural compounds and extracts. This test can show the donation of electrons or hydrogen. In the reaction system, $\mathrm{Fe}^{3+}$ in potassium ferricyanide is reduced to $\mathrm{Fe}^{2+}$ with the addition of antioxidant substance and the resulting Prussian blue color which is observed at $700 \mathrm{~nm}$ [77-79]. The reducing ability of aerial parts of the EEAB and positive controls was found to be descending order of Ascorbic acid (1.520 $\left.\pm 0.028, \mathrm{r}^{2}: 0.9970\right)>$ BHT $\left(1.269 \pm 0.005, \mathrm{r}^{2}: 0.9880\right)>\alpha$ Tocopherol $\left(0.990 \pm 0.007, \mathrm{r}^{2}: 0.9942\right)>\operatorname{EEAB}\left(0.849 \pm 0.001, \mathrm{r}^{2}: 0,9460\right)$ (Table 1 and Figure 1a). The results demonstrated that Astragalus brachycalyx has a high $\mathrm{Fe}^{3+}$ reduction capacity and electron donor 


\section{LC-HRMS profile of Astragalus brachycalyx extracts and theirbiological activities}

ability to neutralize free radicals and ROS. However, this reducing ability was lower than that of standard compounds. In a conducted previous study, reducing power of Astragalus diphtherites and Astragalus gymnalopecias shoot parts at $150 \mu \mathrm{g} / \mathrm{mL}$ concentrations in the methanol extracts are as follows 0.120 and $0.100 \mu \mathrm{g} / \mathrm{mL}$, respectively [80]. It is seen that these results are compatible with the results of the current study.

The CUPRAC test is based on the absorbance measuring at $450 \mathrm{~nm}$ of a stable complex formed between neocuproine and copper ions. A higher absorbance exhibits higher reducing ability of antioxidants [81-83]. $\mathrm{Cu}^{2+}$ ions reducing ability of $30 \mu \mathrm{g} / \mathrm{mL}$ concentrations of positive controls and EEAB are shown in (Table 1 and Figure $1 \mathrm{~b}$ ). $\mathrm{Cu}^{2+}$ ions reducing ability of EEAB and standards at the concentration of $30 \mu \mathrm{g} / \mathrm{mL}$ were found as order of BHT $\left(1.561 \pm 0.089, \mathrm{r}^{2}: 0.9978\right)>$ Ascorbic acid $\left(1.069 \pm 0.007, r^{2}: 0.9722\right)>\alpha$-Tocopherol $\left(0.785 \pm 0.061, r^{2}: 0.9986\right)>\operatorname{EEAB}\left(0.598 \pm 0.003, r^{2}: 0.9996\right)$. According to Haşimi et al. the related results of methanol extracts of Astragalus leporinus and Astragalus schizopterus plants were determined as follows, $50.06 \pm 0.21 \mu \mathrm{g} / \mathrm{mL}$ and $22.35 \pm 0.12 \mu \mathrm{g} / \mathrm{mL}$, respectively [84]. In another study, the $\mathrm{Cu}^{2+}$ reducing results of ethyl acetate extract of Astragalus armatus was determined as $50.60 \pm 0.9 \mu \mathrm{g} / \mathrm{mL}$ [85]. The results of the current study were found to be parallel to the literature.

The last reducing method studied in this regard is the $\mathrm{Fe}^{3+}$-TPTZ reducing ability. This is one of the reduction power methods of $\mathrm{Fe}^{3+}$ to $\mathrm{Fe}^{2+}$ and as a result of it a color change occurs, which has an absorption at $593 \mathrm{~nm}$ [86-88]. The reducing power of EEAB and standards decreased in the following order of Ascorbic acid (1.624 $\left.\pm 0.015, \mathrm{r}^{2}: 0.9930\right)>$ BHT $\left(0.909 \pm 0.006, \mathrm{r}^{2}: 0.9874\right)>\alpha$-Tocopherol $\left(0.755 \pm 0.075, \mathrm{r}^{2}: 0.9867\right)>$ EEAB $\left(0.521 \pm 0.108, \mathrm{r}^{2}: 0.9808\right)$ (Table 1 and Figure 1c). High absorbance values on the basis of this method indicate that the $\mathrm{Fe}^{3+}$-TPTZ complex has strong reduction ability [89]. As a result, EEAB was found to have a strong FRAP reduction ability. When the literature on similar studies was searched, it was seen that there were few studies. In a recent conducted study, the FRAP assay result of the methanol extract of the Astragalus glaucacanthus plant was determined as 0.289 mmol $\mathrm{Fe}^{2+}$ per $\mathrm{g}$ extract [90]. In all reduction methods, EEAB exhibited effective reducing abilities and these activities close to the standards including ascorbic acid, $\alpha$-Tocopherol and BHT.

The DPPH scavenging method is frequently used for evaluation in vitro antioxidant ability of plant extracts as it is a reliable, rapid and reproducible test. The obtained results are commonly expressed as $\mathrm{IC}_{50}$ values. Lower $\mathrm{IC}_{50}$ values indicate stronger antiradical activity [91-93]. As a result of our literature review, we did not find a publication that studied the DPPH or ABTS radical scavenging activity of A. brachycalyx, but a few studies using different species of Astragalus genus are given below. The $\mathrm{IC}_{50}$ values of DPPH scavenging for EEAB and standards were determined in following order of Ascorbic acid (16.116 $\left.\pm 0.003, \mathrm{r}^{2}: 0.9566\right)>\alpha$-Tocopherol $\left(23.1 \pm 0.032, \mathrm{r}^{2}: 0.9825\right)>$ BHT $\left(31.500 \pm 0.011, r^{2}: 0.9754\right)>\operatorname{EEAB}\left(115.5 \pm 0.030, r^{2}: 0.9769\right)$ (Table 2 and Figure 2a). Ascorbic acid was found as most effective DPPH radical scavenging effect when considering other samples. In a previous study [94], DPPH radical removing in 70\% ethanol extract of A. glycyphyllosin flowers; it was found to be $35.64 \mu \mathrm{mol} / \mathrm{g}$ plant. In a recent conducted study, the $\mathrm{IC}_{50}$ result of DPPH radical removing in the methanol extract of Astragalus squarrosus was determined as $1220 \mathrm{mg} / \mathrm{L}$ [95]. When we evaluated all the results together with the current study, it was determined that the highest $\mathrm{IC}_{50}$ values were obtained from Astragalus species according to the standards. It is seen that the EEAB extract does not have a very strong $\mathrm{DPPH}^{\circ}$ removal activity, which is compatible with the literature.

EEAB showed high scavenging activity against $\mathrm{ABTS}$ radicals. The $\mathrm{IC}_{50}$ values of $\mathrm{ABTS}^{++}$ scavenging for EEAB and standards were found in descending order of $\alpha$-Tocopherol $(15.400 \pm 0.003$, $\left.r^{2}: 0.9866\right)>\operatorname{EEAB}\left(16.116 \pm 0.069, r^{2}: 0,9732\right)>$ Ascorbic acid $\left(23.10 \pm 0.001, r^{2}: 0.9998\right)>$ BHT (26.654 $\left.\pm 0.008, \mathrm{r}^{2}: 0.9717\right)$ (Table 2 and Figure $2 \mathrm{~b}$ ). It was determined that $\mathrm{IC}_{50}$ values of $\mathrm{ABTS}^{\cdot+}$ removing of methanol extracts of Astragalus leporinus, Astragalus distinctissimus, Astragalus schizopterus plants as follows, $65.37 \pm 0.44 \mu \mathrm{g} / \mathrm{mL}, 54.71 \pm 0.09 \mu \mathrm{g} / \mathrm{mL}, 22.01 \pm 0.07 \mu \mathrm{g} / \mathrm{mL}$, respectively [84]. In another study, $\mathrm{ABTS}^{++}$removing result in ethyl acetate extract of Astragalus armatus plant was determined as $11.30 \pm 0.09 \mu \mathrm{g} / \mathrm{mL}$ [85]. In our study, the $\mathrm{IC}_{50}$ values obtained for $\mathrm{ABTS}^{{ }^{*+}}$ removing was similar to the above studies. Moreover, it was observed that A. brachycalyx, the subject of our study, had a very strong $\mathrm{ABTS}^{++}$scavenging activity. 
Kızıltaş et.al., J. Chem. Metrol (2021) 15:2 135-151

$1 \mathrm{a}$

$\mathrm{Fe}^{3+}$ Reducing Assay

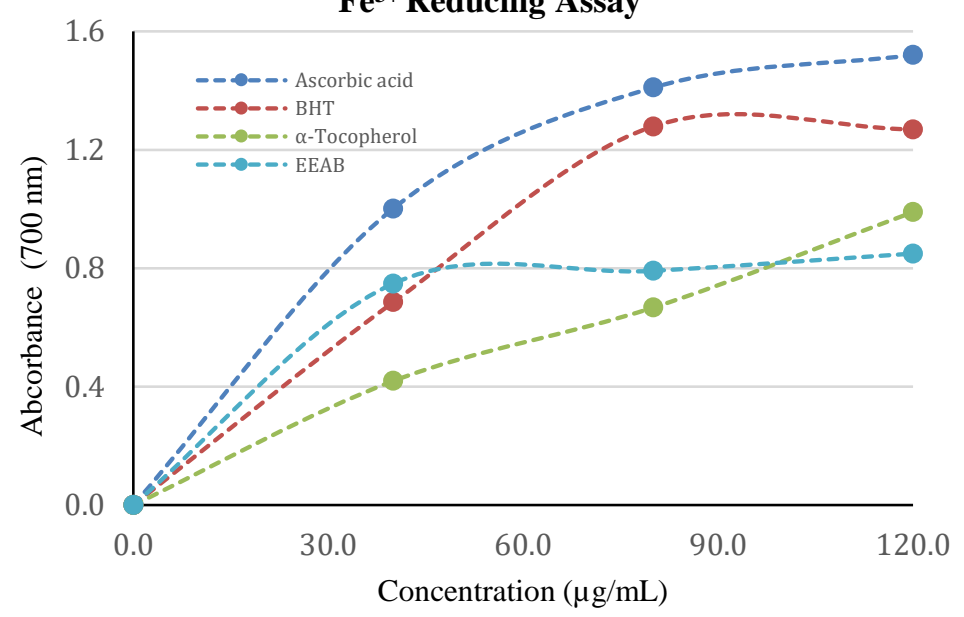

$1 \mathrm{~b}$

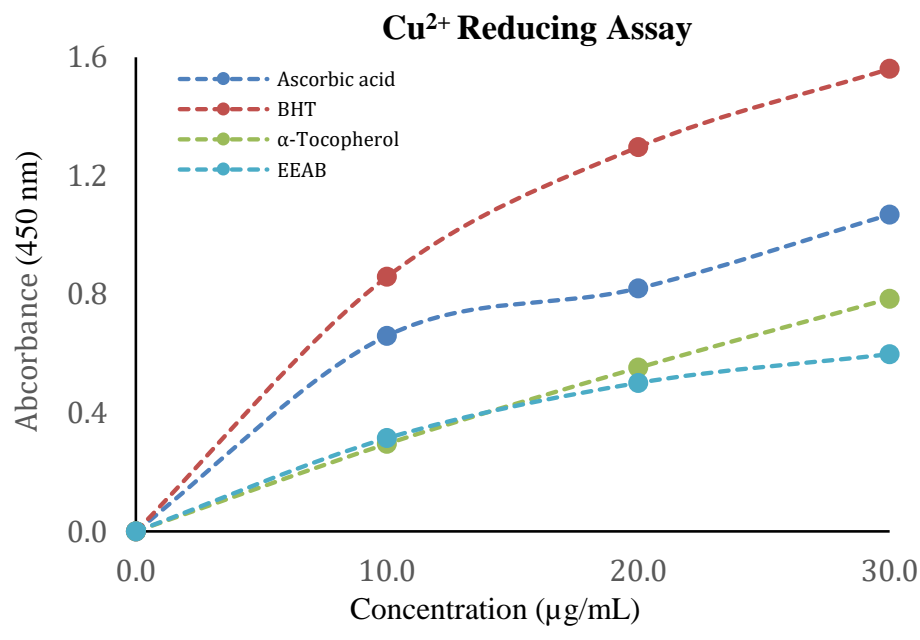

1c

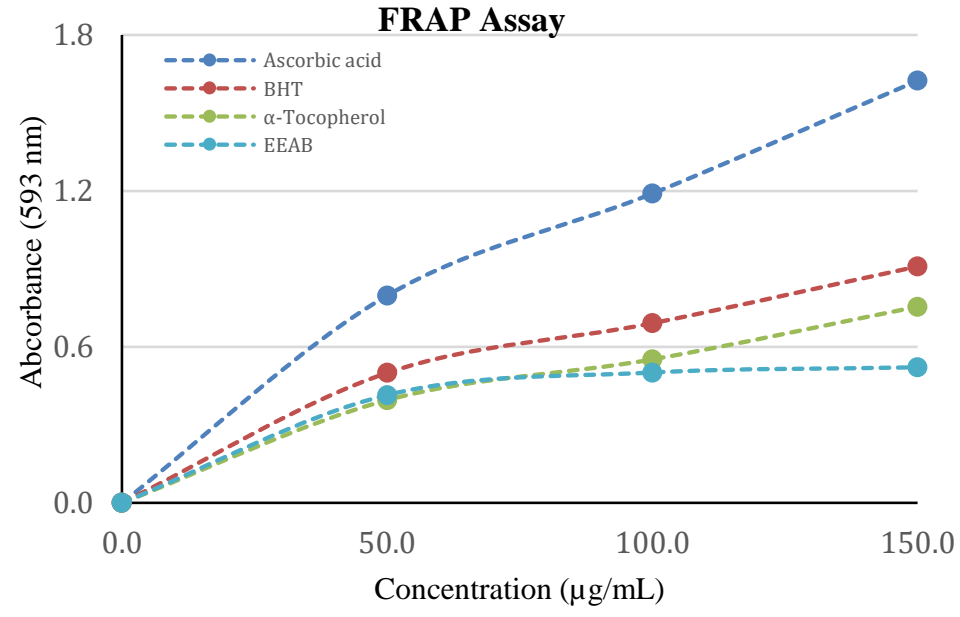

Figure 1. The reducing ability of the EEAB and standards by $\mathrm{Fe}^{3+}$ reducing $(120 \mu \mathrm{g} / \mathrm{mL})(\mathbf{a})$ and $\mathrm{Fe}^{3+}-$ TPTZ reducing (FRAP) $(150 \mu \mathrm{g} / \mathrm{mL})(\mathbf{b})$ and $\mathrm{Cu}^{2+}$ reducing $(30 \mu \mathrm{g} / \mathrm{mL})(\mathbf{c})$ methods 
Table 2. $\mathrm{IC}_{50}$ values $(\mu \mathrm{g} / \mathrm{mL})$ of EEAB and standards for the DPPH and ABTS radicals scavenging and metal chelating activities (EEAB: Evaporated ethanol extract of Astragalus brachycalyx FISCHER)

\begin{tabular}{|c|c|c|c|c|c|c|}
\hline \multirow{2}{*}{ Compounds } & \multicolumn{2}{|c|}{ DPPH・ scavenging } & \multicolumn{2}{|c|}{ ABTS $^{\circ+}$ scavenging } & \multicolumn{2}{|c|}{ Metal chelating } \\
\hline & $\mathrm{IC}_{50} *$ & $\mathbf{r}^{2}$ & $\mathrm{IC}_{50} *$ & $\mathbf{r}^{2}$ & $\mathrm{IC}_{50} *$ & $\mathbf{r}^{2}$ \\
\hline a-Tocopherol & $23.1 \pm 0.032$ & 0.9825 & $15.400 \pm 0.003$ & 0.9866 & $330.0 \pm 0.017$ & 0.9109 \\
\hline Ascorbic acid & $16.116 \pm 0.003$ & 0.9566 & $23.10 \pm 0.001$ & 0.9998 & $99.0 \pm 0.036$ & 0.9985 \\
\hline BHT & $31.500 \pm 0.011$ & 0.9754 & $26.654 \pm 0.008$ & 0.9717 & $14.745 \pm 0.056$ & 0.9646 \\
\hline EEAB & $115.5 \pm 0.030$ & 0.9769 & $16.116 \pm 0.069$ & 0,9732 & $5.095 \pm 0.043$ & 0.9261 \\
\hline
\end{tabular}

Transition metals in biological fluids cause radical degradation by Fenton reaction. Metal chelating is secondary antioxidants, which responsible for metals chelation [85]. When metal chelating activity was evaluated for Astragalus brachycalyx and standards, it was found that EEAB and ascorbic acid had $\mathrm{IC}_{50}$ value of $5.095 \mu \mathrm{g} / \mathrm{mL}$ and $99.0 \mu \mathrm{g} / \mathrm{mL}$, respectively (Table 2 and Figure 2c). EEAB was found the most effective chelating activity. The $\mathrm{IC}_{50}$ values of metal chelating activity of $\mathrm{EEAB}$ and standards decreased in following order of EEAB $\left(5.095 \pm 0.043, \mathrm{r}^{2}: 0.9261\right)>$ BHT $(14.745 \pm 0.056$, $\left.\mathrm{r}^{2}: 0.9646\right)>$ Ascorbic acid $\left(99.0 \pm 0.036, \mathrm{r}^{2}: 0.9985\right)>\alpha$-Tocopherol $\left(330.0 \pm 0.017, \mathrm{r}^{2}: 0.9109\right)$. In a prior conducted study, the metal chelating activity was found to be $17.4 \pm 0.3$ at $100 \mu \mathrm{g} / \mathrm{mL}$ in the ethyl acetate extract of Astragalus armatus [82]. In another study, the metal chelating capacity of flowers and stems of Astragalus glycyphyllos were respectively; $10.09 \mu \mathrm{mol} / \mathrm{g}$ plant; $6.34 \mu \mathrm{mol} / \mathrm{g}$ plant. Also, the metal chelating capacity for the extracts were obtained from the leaves and flowers of the Astragalus cicer was found as 9.94 and $9.90 \mu \mathrm{mol} / \mathrm{g}$, respectively [94]. In a previous conducted study, metal chelating activity of methanol extracts of Astragalus diphtherites and Astragalus gymnalopecias at $25 \mu \mathrm{g} / \mathrm{mL}$ were fond as follows: $4.1 \pm 0.1,22.0 \pm 0.1 \mu \mathrm{g} / \mathrm{mL}$, respectively [80]. When all these results were evaluated, Astragalus brachycalyx has a quite effective metal chelating ability.

The total phenolic and flavonoid contents in EEAB was found to be $23.182 \mu \mathrm{g}$ GAE and 4.672 $\mu \mathrm{g} \mathrm{QE}$, respectively. There was found a positive correlation between total phenolics/flavonoids and antioxidant activity. Biologically active substances such as phenolics and flavonoids are the main components of plants with antioxidant activity [96]. Also, flavonoids are known to be potent inhibitors of several enzymes including xanthine oxidase, cyclooxygenase, and lipoxygenase [97,98]. In a study, the total phenolics and flavonoids in the methanol extract of Astragalus squarrosus were found as 23.3 $\mathrm{mg} / \mathrm{g}$ and $26.0 \mathrm{mg} / \mathrm{g}$, respectively [92]. In another study, the total phenolics and flavonoids in the methanol extracts of the stem parts of Astragalus diphtherites and Astragalus gymnalopecias were found as $76.1 \pm 0.9,54.66 \pm 2.3 \mu \mathrm{g} \mathrm{GAE} / \mathrm{mg}$ and $39.31 \pm 0.2,36.81 \pm 0.3 \mu \mathrm{g} \mathrm{QE} / \mathrm{mg}$ [80]. In this study, it was observed that the results obtained for the total phenolic and flavonoid amounts were compatible with the above studies.

The antioxidant ability of medicinal plants is due to their phenolic and flavonoids contents [99,100]. Phenolic compounds act as hydrogen donors, reducing agents, metal chelators and singlet oxygen quenchers. In this way, they can terminate the oxidation mechanism [101]. In this way, the plants can provide significant protection against oxidative stress and free radical damage. It has been determined that flavonoids, as a main phenolic class, have anti-inflammatory, antiallergic, antiviral and anticarcinogenic properties $[102,103]$. The phenolic content in EEAB was investigated by LC-HRMS analysis and the quantification and identification of thirty-seven phenols were performed in this study (Table 3). The main compound identified in $1 \mathrm{mg}$ of EEAB is fumaric acid $(7229.15 \mathrm{mg} / \mathrm{kg})$ which is a natural organic acid. It finds implementation in nearly every field of industrial chemistry, hispidulin $(5797.94 \mathrm{mg} / \mathrm{kg}$ ) is a medicinal natural compound, which shows strong anticancer properties and luteolin $(722.48 \mathrm{mg} / \mathrm{kg}$ ) that is a natural flavonoid, and it presents in many plant species extensively. Luteolin shows many biological effects such as anti-inflammation, anti-allergy and anticancer and can biochemically act as an antioxidant or a pro-oxidant [104]. When the literature on the subject was searched, no study investigating the phenolic compound content of Astragalus brachycalyx was found, but it was determined that there were studies conducted on different Astragalus species. 
Kızıltaş et.al., J. Chem. Metrol (2021) 15:2 135-151

\section{DPPH• scavenging}
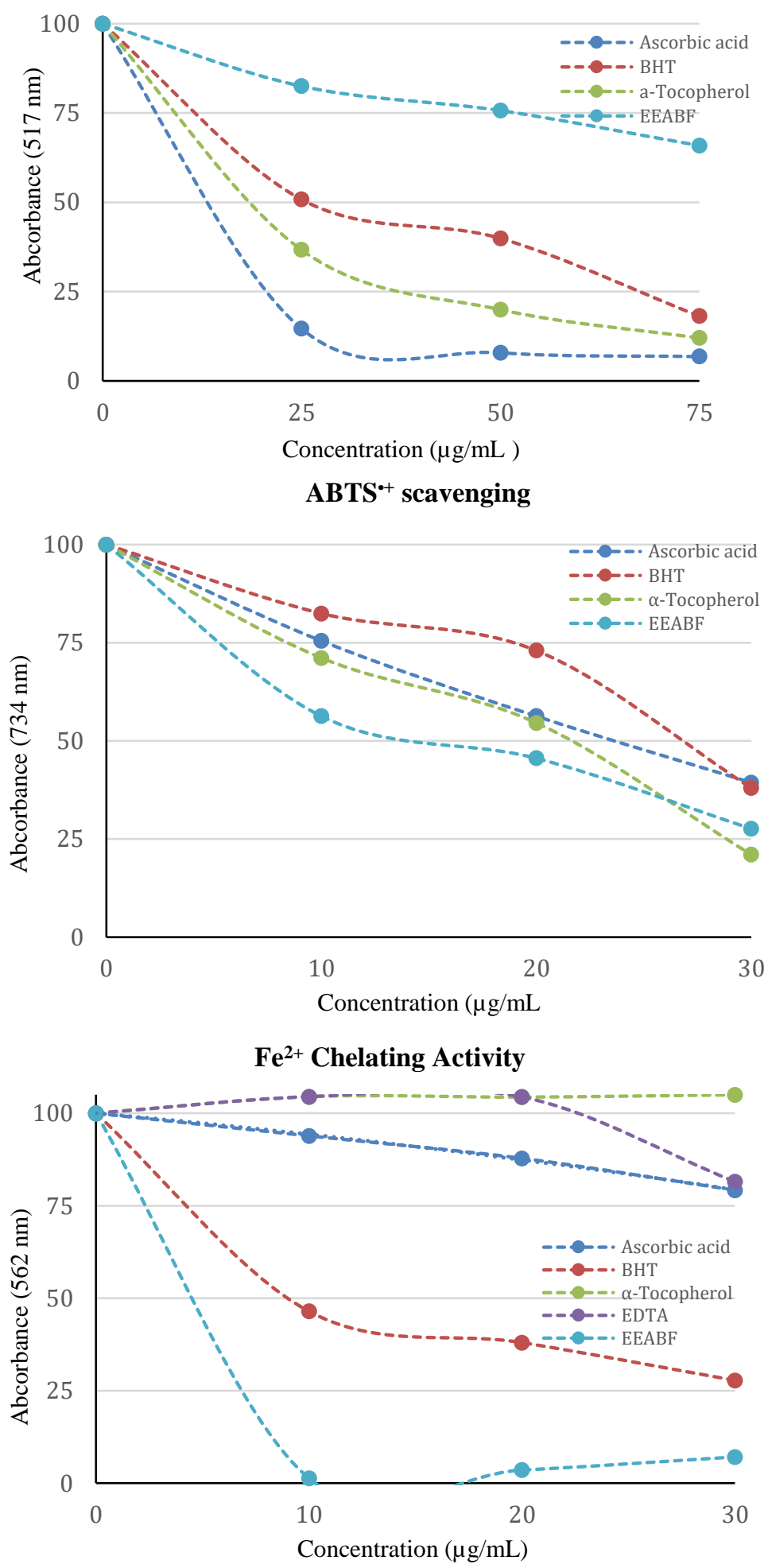

Figure 2. DPPH and ABTS radical scavenging activities and metal binding ability of EEAB and standards

In another recent study in this context, methanolic extracts of A. leporinus, A. distinctissimus and A. schizopterus were analyzed by LC-MS/MS. They reported that the most abundant phenolic compound in all three Astragalus species was rutin (1028.276-13351.76 $\mu \mathrm{g} / \mathrm{g}$ extract) [84]. In a recent study, it was determined that the plentiful phenolic compound was quercetin (353.11 $\mu \mathrm{g} / \mathrm{g}$ extract) [105]. 
LC-HRMS profile of Astragalus brachycalyx extracts and theirbiological activities

In another study carried out recently, methanol extract of Astragalus gymnolobus plant was examined in HPLC-DAD system and rutine (50.48 $\mathrm{mg} \mathrm{g}^{-1}$ dry extract) [106]. Also, the high amount of phenolic content determined in previous studies is similar to the current study results.

Table 4. The quantity ( $\mathrm{mg} / \mathrm{kg}$ extract) of phenolics in EEAB determined by LC-HRMS

\begin{tabular}{|c|c|c|}
\hline Compounds & Quantity (mg/kg) & $\mathrm{U}(\%)$ \\
\hline Ascorbic acid & 223.14 & 3.94 \\
\hline (-)-Epigallocatechin gallate & 2.25 & 3.76 \\
\hline Chlorogenic acid & 160.89 & 3.58 \\
\hline Fumaric acid & 7229.15 & 2.88 \\
\hline (-)-Epicatechin & $<\mathrm{LOD}$ & 3.17 \\
\hline Verbascoside & 303.51 & 2.93 \\
\hline Orientin & $<\mathrm{LOD}$ & 3.67 \\
\hline Caffeic acid & 19.88 & 3.74 \\
\hline$(+)$-Trans taxifolin & 2.27 & 3.35 \\
\hline Luteolin-7-rutinoside & 26.09 & 3.06 \\
\hline Vanillic acid & $<\mathrm{LOD}$ & 3.49 \\
\hline Naringin & $<\mathrm{LOD}$ & 4.20 \\
\hline Luteolin 7-glucoside & $<\mathrm{LOD}$ & 4.14 \\
\hline Hesperidin & $<\mathrm{LOD}$ & 3.79 \\
\hline Rutin & 179.93 & 3.07 \\
\hline Syringic acid & 258.59 & 3.71 \\
\hline Rosmarinic acid & 30.03 & 3.77 \\
\hline Hyperoside & 9.81 & 3.46 \\
\hline Dihydrokaempferol & $<\mathrm{LOD}$ & 2.86 \\
\hline Apigenin 7-glucoside & 9.29 & 3.59 \\
\hline Ellagic acid & $<\mathrm{LOD}$ & 4.20 \\
\hline Quercitrin & $<\mathrm{LOD}$ & 3.78 \\
\hline Nepetin-7-glucoside & $<\mathrm{LOD}$ & 3.07 \\
\hline Quercetin & 8.76 & 2.95 \\
\hline Salicylic acid & 121.44 & 1.89 \\
\hline Naringenin & 280.73 & 4.20 \\
\hline Luteolin & 722.48 & 3.42 \\
\hline Nepetin & 24.17 & 2.19 \\
\hline Apigenin & 585.36 & 2.87 \\
\hline Hispidulin & 5797.94 & 3.41 \\
\hline Isosakuranetin & $<\mathrm{LOD}$ & 3.98 \\
\hline Penduletin & $<\mathrm{LOD}$ & 3.20 \\
\hline Caffeic acid phenethyl ester & 1.11 & 3.13 \\
\hline Chrysin & 11.60 & 3.24 \\
\hline Acacetin & 149.81 & 3.98 \\
\hline Emodin & $<\mathrm{LOD}$ & 4.27 \\
\hline Hederagenin & $<$ LOD & 1.80 \\
\hline
\end{tabular}

Alzheimer's disease (AD) occurs at the molecular level through protein misfolding and aggregation, oxidative stress, mitochondrial abnormalities and neuroinflammatory processes, leading to progressive dementia, memory loss and other cognitive impairments [107,108]. Acetylcholine (ACh), which hydrolyzed by acetylcholinesterase (AChE), is a crucial neurotransmitter in the regulation of learning and memory processes. So, cholinesterase inhibitors increase the level of acetylcholine $[109,110]$. AD is associated with low acetylcholine levels. Therefore, the cholinergic system is under serious 
investigation as it represents an important solution for the treatment of AD. Tacrine, donepezil and galantamine are FDA approved drugs, which improve AD symptoms as clinical AChE inhibitors [111]. Although current AChE inhibitors have documented beneficial effects on cognition and behavior, they have moderate benefits and serious side effects [112]. Therefore, effective therapeutic molecules are being investigated for permanent treatment of $\mathrm{AD}$ [113]. In our study, the results of AChE inhibition linked to $\mathrm{AD}$ were evaluated. It was determined that $\mathrm{EEAB}$ effectively inhibited $\mathrm{AChE}$ with an $\mathrm{IC}_{50}$ value of $1.985 \mu \mathrm{g} / \mathrm{mL}$ ( $\mathrm{r}^{2}: 0.9838$ ). Tacrine was used as positive control for AChE inhibition with an $\mathrm{IC}_{50}$ value of $0.124 \mu \mathrm{M}$ against $\mathrm{AChE}[49,114]$. Although EEAB showed a high inhibition of AChE, this amount of inhibition was found to be very low compared to Tacrine. According to the literature review, while there no study for investigating the cholinesterase inhibition effects of Astragalus brachycalyx. It was determined that there were studies on different Astragalus species. In a recent conducted study, ethyl acetate extract of Astragalus armatus exhibited weak inhibitory effect against $\mathrm{AChE}$ [85]. Also, it was found that AChE inhibition effects of ether extract of Astragalus leporinus, Astragalus distinctissimus, Astragalus schizopterus plants were determined as follows, $46.96 \pm 4.06$, $54.71 \pm 0.09$ and $22.01 \pm 0.07 \%$, respectively [84].

Table 5. $\mathrm{IC}_{50}$ values $(\mu \mathrm{g} / \mathrm{mL})$ of EEAB against $\alpha$-glycosidase, $\alpha$-amylase and acetylcholinesterase

\begin{tabular}{lccc}
\hline \multirow{2}{*}{ Enzymes } & \multicolumn{2}{c}{ EEAB } & Standards \\
\cline { 2 - 4 } & $\mathbf{I C}_{\mathbf{5 0}}(\mu \mathrm{g} / \mathrm{mL})$ & $\mathbf{r}^{\mathbf{2}}$ & $\mathbf{I C}_{\mathbf{5 0}}(\mu \mathrm{M})$ \\
\hline$\alpha$-Glycosidase $^{\mathrm{a}}$ & 0.620 & 0.9526 & 22.80 \\
- $_{\text {-Amylase }}{ }^{\mathrm{a}}$ & 0.306 & 0.9935 & 10.01 \\
Acetylcholinesterase $^{\mathrm{b}}$ & 1.985 & 0.9838 & 0.124 \\
\hline
\end{tabular}

a: Acarbose was used as positive control for $\alpha$-glycosidase and $\alpha$-amylase enzymes and taken from reference 107.

b Tacrine was used as positive control for acetylcholinesterase enzyme and taken from reference of 46.

Type 2 diabetes mellitus (T2DM) is a chronic metabolic disorder manifested by increased blood glucose and insulin resistance. It leads to cardiovascular, nephropathy, retinopathy and neuropathy diseases and ultimately causes serious damage to vessels and nerves [115]. $\alpha$-Amylase and $\alpha$-glycosidase enzymes act as important hydrolytic enzymes in carbohydrate catabolism. It is known that the inhibition of bot enzymes helps lower blood sugar levels [116]. $\alpha$-Glycosidase and $\alpha$-amylase enzymes was conducted to determine the antidiabetic properties of the plants and herbs. The $\mathrm{IC}_{50}$ values for $\alpha$ glycosidase were measured as $0.620 \mu \mathrm{g} / \mathrm{mL}\left(\mathrm{r}^{2}: 0.9526\right)$ for EEAB and $22.80 \mu \mathrm{M}$ for acarbose [107]. In addition to, the $\mathrm{IC}_{50}$ values for $\alpha$-amylase were measured as $0.306 \mu \mathrm{g} / \mathrm{mL}\left(\mathrm{r}^{2}: 0.9935\right)$ for EEAB (Table 5 ). When the results were evaluated, it was seen that EEAB has quite high affinity to $\alpha$-amylase and $\alpha$ glycosidase enzymes. Also, EEAB was more effective than that of acarbose, a standard inhibitor. These results were found to be compatible with our study. Since literature data on AChE, $\alpha$-glycosidase and $\alpha$-amylase inhibitory properties are not available for Astragalus brachycalyx. The present study provides a reference for it for the first time.

This study provides important information about the antioxidant capability, phenolic and flavonoid contents of EEAB, as well as its antidiabetic and anti-Alzheimer properties. It was determined that the ethanol extract of EEAB has a value close to the standard antioxidants. Also, Astragalus brachycalyx was found to have a high content of total phenolic and flavonoids. It was determined by LC-HRMS analysis that fumaric acid, hispidulin and luteolin are major phenolic compounds of EEAB. Also, EEAB showed a high inhibitory effect against AChE, $\alpha$-glycosidase and $\alpha$-amylase enzymes which means have effective anti-AD and antidiabetic activities. Based on these results, it was determined that EEAB, which is the subject of the research, has a natural antioxidant potential that can be used in food and drug applications, and it is thought that the study may be a basis for further phytochemical research. 
LC-HRMS profile of Astragalus brachycalyx extracts and theirbiological activities

\section{Conclusions}

Evaluation of the biological screening including antioxidant effectiveness of EEAB had a great importance. In this context, reducing ability methods were used to provide information on single electron transfer, while radical scavenging methods were used as indicator radicals that can be neutralized by reduction via electron transfers as well as quenching via hydrogen atom transfer. mechanism. The EEAB was analyzed for its antioxidant activities and bioactivities including inhibitory properties of some metabolic enzymes associated with some global diseases. In addition, a positive correlation was found between the total phenolic or flavonoid contents of EEAB and its biological ability. Also, when the chromatographic results were evaluated, it was seen that the main biological activities of the EEAB were hispidulin, luteolin and apigenin. Ethanol was observed as an effective solvent for the extraction procedure of phenolics with effective antioxidant and enzyme inhibition abilities. Nowadays, enzyme inhibition had crucial importance for controlling overactive enzyme has become a key target to treated many chronic diseases including cancer, $\mathrm{AD}$ and diabetes.

\section{Acknowledgement}

S. Alwasel would like to extend his sincere appreciation to the Researchers Supporting Project (RSP-2021/59), King Saud University, Saudi Arabia, for support.

$$
\begin{array}{ll}
\text { ORCID } & \\
\text { Hatice Kızıltaş } & : \underline{0000-0002-0833-3358} \\
\text { Zeynebe Bingöl } & : \underline{0000-0003-3373-779 X} \\
\text { Ahmet C. Gören } & : \underline{0000-0002-5470-130 X} \\
\text { Suleyman Mesut Pinar } & : \underline{0000-0002-1774-7704} \\
\text { Saleh H. Alwasel } & : \underline{0000-0002-0626-2306} \\
\text { İlhami Gülçin } & : \underline{0000-0001-5993-1668}
\end{array}
$$

\section{References}

[1] M.M.A. El-Ghani, A.S.A. El-Sayed, A. Moubarak, R. Rashad, H. Nosier and A. Khattab (2021). Biosystematic study on some Egyptian species of Astragalus L. (Fabaceae), Agriculture 11, 125.

[2] S. Albayrak and O. Kaya (2018). Antioxidant and antimicrobial activities of four Astragalus species growing wild in Turkey, Turk. J. Biochem. 43, 425-434.

[3] M.A. Berezutskii, L.R. Yakubova, N.A. Durnova, Y.V. Romanteeva, Y.V., Belonogova, E.E. Komarova, and A.S. Sheremet'eva (2020). Pharmacological properties of preparations based on Astragalus extract (Review), Pharm. Chem. J. 54, 372-376.

[4] Y. Demir, L. Durmaz, P. Taslimi and İ. Gülçin (2019). Anti-diabetic properties of dietary phenolic compounds: inhibition effects on $\alpha$-amylase, aldose reductase and $\alpha$-glycosidase, Biotechnol. Appl. Biochem. 66(5), 781-786.

[5] M. Adnan, A.J. Siddiqui, A. Jamal, W.S. Hamadou, A.M. Awadelkareem, M. Sachidanandan and M. Patel (2021). Evidence-based medicinal potential and possible role of Selaginella in the prevention of modern chronic diseases: Ethnopharmacological and ethnobotanical perspective, Rec. Nat. Prod. 15(5), 330-355.

[6] B. Aslanipour, D. Gülcemal, A. Nalbantsoy, H. Yusufoglu and E. Bedir (2017). Cycloartane-type glycosides from Astragalus brachycalyx FISCHER and their effects on cytokine release and hemolysis, Phytochem. Lett. 21, 66-73.

[7] M. Küçük and İ. Gulcin (2016). Purification and characterization of carbonic anhydrase enzyme from black sea trout (Salmo trutta Labrax coruhensis) kidney and inhibition effects of some metal ions on the enzyme activity, Environ. Toxicol. Pharmacol. 44,134-139.

[8] C. Caglayan, P. Taslimi, C. Türk, F.M. Kandemir, Y. Demir and I. Gulcin (2019). Purification and characterization of the carbonic anhydrase enzyme from horse mackerel (Trachurus trachurus) muscle and the impact of some metal ions and pesticides on enzyme activity. Comp. Biochem. Physiol. Part-C: Toxicol. Pharmacol. 226, 108605. 
[9] H.T. Balaydın, I. Gulcin, A. Menzek, S. Göksu and E. Şahin (2010). Synthesis and antioxidant properties of diphenylmethane derivative bromophenols including a natural product, J. Enzyme Inhib. Med. Chem. 25(5), 685-695.

[10] E. Koksal and I. Gulcin, (2008). Antioxidant activity of cauliflower (Brassica oleracea L.), Turk. J. Agric. For. 32, 65-78.

[11] I. Gulcin, V. Mshvildadze, A. Gepdiremen and R. Elias (2006). Antioxidant activity of a triterpenoid glycoside isolated from the berries of Hedera colchica: 3-O-( $\beta$-D-glucopyranosyl)-hederagenin, Phytother. Res. 20(2), 130-134.

[12] H. Tohma, I. Gulcin, E. Bursal, A.C. Gören, S.H. Alwasel and E. Köksal (2017). Antioxidant activity and phenolic compounds of ginger (Zingiber officinale Rosc.) determined by HPLC-MS/MS, J. Food Measure. Charac. 11(2), 556-566.

[13] I. Gulcin, F. Topal, S.B. Oztürk Sarikaya, E. Bursal, A.C. Gören and M. Bilsel (2011). Polyphenol contents and antioxidant properties of medlar (Mespilus germanica L.), Rec. Nat. Prod. 5(3), 158-175.

[14] M. Elmastas, İ. Türkekul, L. Öztürk, I. Gulcin, Ö. Işı1ldak and H.Y. Aboul-Enein (2006). The antioxidant activity of two wild edible mushrooms (Morchella vulgaris and Morchella esculanta), Comb. Chem. High Throughput Screen. 9(6), 443-448

[15] R. Arumugam, B. Kirkan and C. Sarikurkcu (2019). Phenolic profile, antioxidant and enzyme inhibitory potential of methanolic extracts from different parts of Astragalus ponticus Pall. South Afr. J. Bot. 120, 268-273.

[16] H. Kızıltaş, Z. Bingol, A.C. Goren, S.H. Alwasel and İ. Gülçin (2021). Anticholinergic, antidiabetic and antioxidant activities of Ferula orientalis L.-Analysis of its polyphenol contents by LC-HRMS, Rec. Nat. Prod. 15(6), 513-528.

[17] I. Gulcin, Ş. Beydemir, İ.G. Şat and Ö.İ. Küfrevioğlu (2005). Evaluation of antioxidant activity of cornelian cherry (Cornus mas L.), Acta Aliment. Hung. 34(2), 193-202.

[18] İ. Gülçin, İ.G. Şat, Ş. Beydemir and Ö.İ. Küfrevioğlu (2004). Evaluation of the in vitro antioxidant properties of extracts of broccoli (Brassica oleracea L.), Ital. J. Food Sci. 16(1), 17-30.

[19] Z. Huyut, S. Beydemir and I. Gulcin (2017). Antioxidant and antiradical properties of some flavonoids and phenolic compounds, Biochem. Res. Int. 7616791.

[20] I. Gulcin and A. Daştan (2007). Synthesis of dimeric phenol derivatives and determination of in vitro antioxidant and radical scavenging activities, J. Enzyme Inhib. Med. Chem. 22(6), 685-695.

[21] I. Gulcin (2012). Antioxidant activity of food constituents: An overview, Arch. Toxicol. 86(3), 345-391

[22] I. Gulcin (2020). Antioxidants and antioxidant methods-An updated overview, Arch. Toxicol. 94, 651715.

[23] C. Cağlayan, P. Taslimi, Y. Demir, S. Küçükler, M.F. Kandemir and İ. Gülçin (2019). The effects of zingerone against vancomycin-induced lung, liver, kidney and testis toxicity in rats: the behavior of some metabolic enzymes, J. Biochem. Mol. Toxicol. 33(10), e22381.

[24] N. Eruygur, M. Ataş, M. Tekin, P. Taslimi, U.M. Koçyiğit and I. Gulcin (2019). In vitro antioxidant, antimicrobial, anticholinesterase and antidiabetic activities of Turkish endemic Achillea cucullata (Asteraceae) from ethanol extract, South Afr. J. Bot. 120, 141-145.

[25] E. Koksal, E. Bursal, I. Gulcin, M. Korkmaz, C. Çağlayan, A.C. Goren and S.H. Alwasel (2017). Antioxidant activity and polyphenol content of Turkish thyme (Thymus vulgaris) monitored by LCMS/MS, Int. J. Food Prop. 20(3), 514-525.

[26] M. Topal, H. Gocer, F. Topal, P. Kalin, P. Polat Köse, İ. Gülçin, K.C. Çakmak, M. Küçük, L. Durmaz, A.C. Gören and S.H. Alwasel, (2016). Antioxidant, antiradical and anticholinergic properties of cynarin purified from the illyrian thistle (Onopordum illyricum L.), J. Enzyme Inhib. Med. Chem. 31, 266-275.

[27] E. Bursal, P. Taslimi, A. Gören and I. Gulcin (2020). Assessments of anticholinergic, antidiabetic, antioxidant activities and phenolic content of Stachys annua, Biocat. Agric. Biotechnol. 28, 101711.

[28] I. Gulcin, A.C. Gören, P. Taslimi, S.H. Alwasel, O. Kilic and E. Bursal (2020). Anticholinergic, antidiabetic and antioxidant activities of Anatolian pennyroyal (Mentha pulegium)-analysis of its polyphenol contents by LC-MS/MS, Biocat. Agric. Biotechnol. 23, 101441.

[29] K. Çetin Çakmak and I. Gulcin (2019). Anticholinergic and antioxidant activities of usnic acid-an activitystructure insight, Toxicol. Rep. 6, 1273-1280.

[30] I. Gulcin, P. Taslimi, A. Aygün, N. Sadeghian, E. Bastem, Ö.İ. Küfrevioğlu, F. Turkan and F. Şen (2018). Antidiabetic and antiparasitic potentials: Inhibition effects of some natural antioxidant compounds on $\alpha$ glycosidase, $\alpha$-amylase and human glutathione S-transferase enzymes, Int. J. Biol. Macromol. 119, 741746.

[31] P. Taslimi and I. Gulcin (2018). Antioxidant and anticholinergic properties of olivetol, J. Food Biochem. 42(3), e12516. 


\section{LC-HRMS profile of Astragalus brachycalyx extracts and theirbiological activities}

[32] I. Gulcin (2005). The antioxidant and radical scavenging activities of black pepper (Piper nigrum) seeds, Int. J. Food Sci. Nutr. 56(7), 491-499.

[33] I. Gulcin, E. Bursal, H.M. Şehitoğlu, M. Bilsel and A.C. Gören (2010). Polyphenol contents and antioxidant activity of lyophilized aqueous extract of propolis from Erzurum, Turkey. Food Chem. Toxicol. 48 (8-9), 2227-2238.

[34] L. Polat Köse, I. Gulcin, A.C. Gören, J. Namiesnik, A.L. Martinez-Ayala and S. Gorinstein, (2015). LCMS/MS analysis, antioxidant and anticholinergic properties of galanga (Alpinia officinarum Hance) rhizomes, Ind. Crops Prod. 74, 712-721.

[35] M. Topal (2020). Secondary metabolites of ethanol extracts of Pinus sylvestris cones from eastern Anatolia and their antioxidant, cholinesterase and alpha-glucosidase activities. Rec. Nat. Prod. 14, 129138.

[36] P. Kalın, I. Gulcin and A.C. Gören (2015). Antioxidant activity and polyphenol content of cranberries (Vaccinium macrocarpon), Rec. Nat. Prod. 9, 496-502.

[37] E. Bursal, A. Aras, Ö. Kılıç, P. Taslimi, A.C. Gören and I. Gulcin (2019). Phytochemical content, antioxidant activity and enzyme inhibition effect of Salvia eriophora Boiss. \& Kotschy against acetylcholinesterase, $\alpha$-amylase, butyrylcholinesterase and $\alpha$-glycosidase enzymes, J. Food Biochem. 43(3), e12776.

[38] T. Artunç, A. Menzek, P. Taslimi, I. Gulcin, C. Kazaz and E. Şahin (2020). Synthesis and antioxidant activities of phenol derivatives from 1,6-bis(dimethoxyphenyl)hexane-1,6-dione, Bioorg. Chem. 100, 103884

[39] İ. Gülçin, R. Elias, A. Gepdiremen and L. Boyer (2006). Antioxidant activity of lignans from fringe tree (Chionanthus virginicus L.), Eur. Food Res. Technol. 223, 759-767.

[40] İ. Gülçin, R. Elias, A. Gepdiremen, L. Boyer and E. Köksal (2007). A comparative study on the antioxidant activity of fringe tree (Chionanthus virginicus L.) extracts, Afr. J. Biotechnol. 6(4), 410-418.

[41] R. Apak, K. Güçlü, M. Özyürek, S.E. Karademir and E. Erça (2006). The cupric ion reducing antioxidant capacity and polyphenolic content of some herbal teas, Int. J. Food Sci. Nutr. 57, 292-304.

[42] T. Ak and İ. Gülçin (2008). Antioxidant and radical scavenging properties of curcumin, Chem. Biol. Interact. 174, 27-37.

[43] I. Gulcin, A.Z. Tel, A.C. Gören, P. Taslimi and S. Alwasel (2019). Sage (Salvia pilifera): Determination its polyphenol contents, anticholinergic, antidiabetic and antioxidant activities, J. Food Measure. Charac. 13(3), 2062-2074.

[44] S. Çakmakçı, E.F. Topdaş, P. Kalın, H. Han, P. Şekerci, L. Polat Kose and İ. Gülçin (2015). Antioxidant capacity and functionality of oleaster (Elaeagnus angustifolia L.) flour and crust in a new kind of fruity ice cream, Int. J. Food Sci. Technol. 50(2), 472-481.

[45] M. Rezai, Ç. Bayrak, P. Taslimi, I. Gulcin and A. Menzek (2018). The first synthesis, antioxidant and anticholinergic activities of 1-(4,5-dihydroxybenzyl)pyrrolidin-2-one derivative bromophenols including natural products, Turk. J. Chem. 42(3), 808-825.

[46] I. Gulcin, R. Kaya, A.C. Gören, H. Akıncıŏlu, M. Topal, Z. Bingöl, K. Çetin Çakmak, S.B. Ozturk Sarikaya, L. Durmaz and S. Alwasel (2019). Anticholinergic, antidiabetic and antioxidant activities of Cinnamon (Cinnamomum verum) bark extracts: Polyphenol contents analysis by LC-MS/MS, Int. J. Food Prop. 22, 1511-1526.

[47] F. Turkan, M.N. Atalar, A. Aras, I. Gulcin and E. Bursal (2020). ICP-MS and HPLC analyses, enzyme inhibition and antioxidant potential of Achillea schischkinii Sosn, Bioorg. Chem. 94, 103333.

[48] Y. Çetinkaya, H. Göçer, A. Menzek and I. Gulcin (2012). Synthesis and antioxidant properties of (3,4dihydroxyphenyl) (2,3,4-trihydroxyphenyl)methanone and its derivatives, Arch. Pharm. 345, 323-334.

[49] P. Taslimi, E. Koksal, A.C. Gören, E. Bursal, A. Aras, O. Kılıç, S. Alwasel and I. Gulcin (2020). AntiAlzheimer, antidiabetic and antioxidant potential of Satureja cuneifolia and analysis of its phenolic contents by LC-MS/MS, Arab. J. Chem. 13(3), 4528-4537.

[50] M.S. Blois (1958) Antioxidant determinations by the use of a stable free radical, Nature 26, 1199-1200.

[51] L. Polat Köse, Z. Bingöl, R. Kaya, A.C. Gören, H. Akincioğlu, L. Durmaz, E. Koksal, S. Alwasel and I. Gulcin (2020). Anticholinergic and antioxidant activities of avocado (Folium perseae) leavesphytochemical content by LC-MS/MS analysis, Int. J. Food Prop. 23, 878-893.

[52] N. Öztaskin, R. Kaya, A. Maraş, E. Sahin, I. Gulcin and S. Göksu (2019). Synthesis and characterization of novel bromophenols: Determination of their anticholinergic, antidiabetic and antioxidant activities, Bioorg. Chem. 87, 91-102.

[53] E. Bursal and I. Gulcin (2011). Polyphenol contents and in vitro antioxidant activities of lyophilized aqueous extract of kiwifruit (Actinidia deliciosa), Food Res. Int. 44(5), 1482-1489.

[54] I. Gulcin, B. Trofimov, R. Kaya, P. Taslimi, L. Sobenina, E. Schmidt, O. Petrova, S. Malysheva, N. Gusarova, V. Farzaliyev, A. Sujayev, S. Alwasel and C.T. Supuran (2020). Synthesis of nitrogen, 
phosphorus, selenium and sulfur-containing heterocyclic compounds-determination of their carbonic anhydrase, acetylcholinesterase, butyrylcholinesterase and $\alpha$-glucosidase inhibition properties, Bioorg. Chem. 103, 104171.

[55] H. Genç Bilgiçli, D. Ergön, P. Taslimi, B. Tüzün, İ. Akyazı Kuru, M. Zengin and I. Gulcin (2020). Novel propanolamine derivatives attached to 2-metoxifenol moiety: Synthesis, characterization, biological properties, and molecular docking studies, Bioorg. Chem. 101, 103969.

[56] I. Gulcin, A. Scozzafava, C.T. Supuran, H. Akıncioğlu, Z. Koksal, F. Turkan and S. Alwasel (2016). The effect of caffeic acid phenethyl ester (CAPE) metabolic enzymes including acetylcholinesterase, butyrylcholinesterase, glutathione s-transferase, lactoperoxidase and carbonic anhydrase isoenzymes I, II, IX and XII, J. Enzyme Inhib. Med. Chem. 31(6), 1095-1101.

[57] M. Zengin, I. Gulcin, P. Taslimi, A. Kestane, E. Güçlü, A. Ögütlü, O. Karabay and İ. Gülçin (2018). Novel thymol bearing oxypropanolamine derivatives as potent some metabolic enzyme inhibitors-their antidiabetic, anticholinergic and antibacterial potentials, Bioorg. Chem. 81, 119-126.

[58] P. Taslimi, H.E. Aslan, Y. Demir, N. Öztaşkın, A. Maraş, I. Gulcin, Ş. Beydemir and S. Göksu (2018). Diarilmethanon, bromophenols and diarilmetan compounds: discovery of potent aldose reductase, $\alpha$ amylase and $\alpha$-glycosidase inhibitors as new therapeutic approach in diabetes and functional hyperglycemia, Int. J. Biol. Macromol. 119, 857-863.

[59] N. Lolak, S. Akocak, C. Turkes, P. Taslimi, M. Işık, Ş. Beydemir, I. Gulcin and M. Durgun (2020). Synthesis, characterization, inhibition effects, and molecular docking studies as acetylcholinesterase, $\alpha-$ glycosidase, and carbonic anhydrase inhibitors of novel benzenesulfonamides incorporating 1,3,5triazine structural motifs, Bioorg. Chem. 100, 103897.

[60] A. Karimov, A. Orujova, P. Taslimi, N. Sadeghian, B. Mammadov, H.S. Karaman, V. Farzaliyev, A., Sujayev, R. Taş, S. Alwasel and I. Gulcin (2020). Novel functionally substituted esters based on sodium diethyldithiocarbamate derivatives: synthesis, characterization, biological activity and molecular docking studies, Bioorg. Chem. 99, 103762.

[61] S. Hashmi, S. Khan, Z. Shafiq, P. Taslimi, M. Ishaq, N. Sadeghian, S.H. Karaman, N. Akhtar, M. Islam, A. Asari, H. Mohamad and İ. Gulçin (2021). Probing 4-(diethylamino)-salicylaldehyde-based thiosemicarbazones as multi-target directed ligands against cholinesterases, carbonic anhydrases and $\alpha$ glycosidase enzymes, Bioorg. Chem. 107, 104554.

[62] Z. Xiao, R. Storms and A. Tsang (2006). A quantitative starch-iodine method for measuring alphaamylase and glucoamylase activities, Anal. Biochem. 351, 146-148.

[63] H. Lineweaver and D. Burk (1934). The determination of enzyme dissociation constant, J. Am. Chem. Soc. 56, 658-666.

[64] C. Caglayan, P. Taslimi, C. Türk, I. Gulcin, F.M. Kandemir, Y. Demir and S. Beydemir (2020). Inhibition effects of some pesticides and heavy metals on carbonic anhydrase enzyme activity purified from horse mackerel (Trachurus trachurus) gill tissues, Environ. Sci. Poll. Res. 27, 10607-10616.

[65] D. Ozmen Ozgun, C. Yamali, H.I.. Gül, P. Taslimi, I. Gulcin, T. Yanik and C.T. Supuran (2016). Inhibitory effects of isatin Mannich bases on carbonic anhydrases, acetylcholinesterase and butyrylcholinesterase, J. Enzyme Inhib. Med. Chem. 31(6), 1498-1501.

[66] B. Özgeriş, S. Göksu, L. Köse Polat, I. Gulcin, R.E. Salmas, S. Durdagi, F. Tümer and C.T. Supuran (2016). Acetylcholinesterase and carbonic anhydrase inhibitory properties of novel urea and sulfamide derivatives incorporating dopaminergic 2 -aminotetralin scaffolds, Bioorg. Med. Chem. 24, 2318-2329.

[67] H.O. Hamad, M.H. Alma, I. Gulcin, M.A. Yılmaz and E. Karaoğul (2017). Evaluation of phenolic contents and bioactivity of root and nutgall extracts from Iraqian Quercus infectoria Olivier, Rec. Nat. Prod. 11, 205-210.

[68] H. Kızıltaş, Z. Bingöl, A.C. Gören, L. Polat Köse, L. Durmaz, F. Topal, S.H. Alwasel and İ. Gulçin (2021). LC-HRMS profiling, antidiabetic, anticholinergic and anti-oxidant activities of aerial parts of kınkor (Ferulago stelleta), Molecules 26, 2469.

[69] Z. Bingöl, H. Kızıltaş, A.C. Gören, L. Polat Köse, M. Topal, L. Durmaz, S.H. Alwasel and İ. Gulçin (2021). Antidiabetic, anticholinergic and antioxidant activities of aerial parts of shaggy bindweed (Convulvulus betonicifolia Miller subsp.)-profiling of phenolic compounds by LC-HRMS, Heliyon 7, e06986.

[70] H. Han, H. Yllmaz and I. Gulcin (2018). Antioxidant activity of flaxseed (Linum usitatissimum L.) and analysis of its polyphenol contents by LC-MS/MS, Rec. Nat. Prod. 14, 340-354.

[71] A.C. Goren, G. Bilsel and M. Bilsel (2007). Rapid and simultaneous determination of 25-OH-vitamin D2 and D3 in human serum by LC/MS/MS: Validation and uncertainty assessment, J. Chem. Metrol. 1, 1-9.

[72] Z. Özer, S. Çarıkçı, H. Yılmaz, T. Kılıç, T. Dirmenci and A.C. Gören (2020). Determination of secondary metabolites of Origanum vulgare subsp. hirtum and $O$. vulgare subsp. vulgare by LC-MS/MS, J. Chem. Metrol. 14, 25-34. 


\section{LC-HRMS profile of Astragalus brachycalyx extracts and theirbiological activities}

[73] S. Karakaya, Z. Bingöl, M. Koca, B. Demirci, İ. Gulçin and H.K.C. Başer (2020). Screening of nonalkaloid acetylcholinesterase and carbonic anhydrase isoenzymes inhibitors of Leiotulus dasyanthus (K. Koch) Pimenov \& Ostr. (Apiaceae), J. Essen. Oil Res. 32(3), 227-241.

[74] A. Aras, E. Bursal, F. Turkan, H. Tohma, O. Kılıç, I. Gülçin and E. Köksal (2019). Phytochemical content, antidiabetic, anticholinergic, and antioxidant activities of endemic Lecokia cretica extracts. Chem. Biodiver. 16(10), e1900341.

[75] H. Tohma, A. Altay, E. Koksal, A.C. Gören and İ. Gülçin (2019). Measurement of anticancer, antidiabetic and anticholinergic properties of sumac (Rhus coriaria)-Analysis of its phenolic compounds by LCMS/MS. J. Food Measure. Charac. 13(2), 1607-1619.

[76] A. Labed, M. Ferhat, I. Labed-Zouad, E. Kaplaner, S. Zerizer, L. Voutquenne-Nazabadioko, A.A. Magid, Z. Semra, A. Kabouche, Z. Kabouche and M. Öztürk (2016). Compounds from the pods of Astragalus armatus with antioxidant, anticholinesterase, antibacterial and phagocytic activities, Pharm. Biol. 54(12), 3026-3032.

[77] H. Shang, M. Wang, R. Li, M. Duan, H. Wu and H. Zhou (2018). Extraction condition optimization and effects of drying methods on physicochemical properties and antioxidant activities of polysaccharides from Astragalus cicer L. Sci. Rep. 8, 3359, 1-12.

[78] E. Koksal, S.H. Tohma, Ö. Kılıç, Y. Alan, A. Aras, İ. Gulcin and E. Bursal (2017). Assessment of antimicrobial and antioxidant activities of Nepeta trachonitica-Analysis of its phenolic compounds using HPLC-MS/MS, Sci. Pharm. 15, 85(2).

[79] İ. Gülçin, M. Oktay, E. Köksal, H. Şerbetçi, Ş. Beydemir and Ö.I. Küfrevioglu (2008). Antioxidant and radical scavenging activities of uric acid, Asian J. Chem. 20(3), 2079-2090.

[80] C. Keskin, H.Ç. Özen, Z. Toker, G. Kızıl and M. Kızıl (2018). Astragalus diphtherites FENZL var diphtherites ve Astragalus gymnalopecias RECH. FIL'in gövde ve kök kısımlarından farklı çözücüler ile elde edilen özütlerin invitro antioksidan ve antimikrobiyal özelliklerinin belirlenmesi. KSU J. Agric Nat. 21(2), 157-166.

[81] K. Aksu, B. Özgeriş, P. Taslimi, A. Naderi, İ. Gülçin and S. Göksu (2016). Antioxidant activity, acetylcholinesterase and carbonic anhydrase inhibitory properties of novel ureas derived from phenethylamines, Arch. Pharm. 349(12), 944-954.

[82] H. Tohma, E. Köksal, Ö. Kılıç, Y. Alan, M.A. I. Yılmaz, I. Gulcin, E. Bursal and S.H. Alwasel (2016). RP-HPLC/MS/MS analysis of the phenolic compounds, antioxidant and antimicrobial activities of Salvia L. species, Antioxidants 5, 38 .

[83] J.H. Bae, Y.J. Park, J. Namiesnik, İ. Gülçin, T.C. Kim, H.C. Kim, B.G. Heo, S. Gorinstein and Y.G. Ku (2016). Effects of artificial lighting on bioactivity of sweet red pepper (Capsicum annuum L.), Int. J. Food Sci. Technol. 51(6), 1378-1385.

[84] N. Haşimi, A. Ertaş, M.A. Yılmaz, M. Boğa, H. Temel, S. Demirci, T.Y. Özden, İ. Yener and U. Kolak, (2017). LC-MS/MS and GC-MS analyses of three endemic Astragalus species from Anatolia towards their total phenolic flavonoid contents and biological activities, Biodivers. Conserv. 10(1),18-30.

[85] A. Labed, M. Ferhat, I. Labed-Zouad, E. Kaplaner, S. Zerizer, L. Voutquenne-Nazabadioko, A.A. Magid, Z. Semra, A. Kabouche, Z. Kabouche and M. Öztürk (2016). Compounds from the pods of Astragalus armatus with antioxidant, anticholinesterase, antibacterial and phagocytic activities, Pharm. Biol. 54(12), 3026-3032.

[86] J. Benites, D. Rios, A. Guerrero-Castilla, C. Enriquez, E. Zavala, R.O. Ybanez-Julca, I. Quispe-Diaz, R. Jara-Aguilar and P.B. Calderon (2021). Chemical composition and assessment of antimicrobial, antioxidant and antiproliferative activities of essential oil from Clinopodium sericeum, a peruvian medicinal plant, Rec. Nat. Prod. 15(3), 175-186.

[87] N. Oztaskın, Y. Çetinkaya, P. Taslimi, S. Göksu and İ. Gülçin (2015). Antioxidant and acetylcholinesterase inhibition properties of novel bromophenol derivatives, Bioorg. Chem. 60, 49-57.

[88] M.H. Sehitoglu, H. Han, P. Kalin, İ. Gülçin, A. Ozkan and H.Y. Aboul-Enein (2015). Pistachio (Pistacia vera L.) gum: A potent inhibitor of reactive oxygen species, J. Enzyme Inhib. Med. Chem. 30, 264-269.

[89] İ. Gülçin, M. Elmastaş and H.Y. Aboul-Enein (2012). Antioxidant activity of clove oil-A powerful antioxidant source, Arab. J. Chem. 5(4), 489-499.

[90] S. Langari and E.A. Salehi (2015). Evaluation of the antioxidant capacity of different extracts of Astragalus glaucacanthus, J. Appl. Environ. Biol. Sci. 4(11S), 14-17.

[91] Y. Çetinkaya, H. Göçer, A. Menzek and İ. Gülçin (2012). Synthesis and antioxidant properties of (3,4dihydroxyphenyl)(2,3,4-trihydroxyphenyl)methanone and its derivatives, Arch. Pharm. 345, 323-334.

[92] İ. Gülçin, F. Topal, R. Çakmakçı, A.C. Gören, M. Bilsel and U. Erdoğan (2011). Pomological features, nutritional quality, polyphenol content analysis and antioxidant properties of domesticated and three wild ecotype forms of raspberries (Rubus idaeus L.), J. Food Sci. 76(4), C585-C593. 
[93] İ. Gülçin (2011). Antioxidant activity of eugenol-a structure and activity relationship study, J. Med. Food, 14(9), 975-985.

[94] B. Butkut, A. Dagilyt, R. Benetis, A. Padarauskas, J. Cesevilien, V. Olšauskait and N. Lemedien (2018). Mineral and phytochemical profiles and antioxidant activity of herbal material from two temperate astragalus species, BioMed Res. Int. 2018, 1-11

[95] J. Asgarpanah, S.M. Motamed, A. Farzaneh, B. Ghanizadeh and S. Tomraee, (2011). Antioxidant activity and total phenolic and flavonoid content of Astragalus squarrosus Bunge, Afr. J. Biotechnol. 10(82), 19176-19180.

[96] A. Baghiani, N. Boussoualim, H. Trabsa, S. Aouachria and L. Arrar (2013). In vivo free radical scavenging, antihemolytic activity and antibacterial effects of Anchusa Azurea extracts, Int. J. Med. Med. Sci. 46(1), 1113-1118.

[97] H. Şerbetçi Tohma and İ. Gülçin (2010). Antioxidant and radical scavenging activity of aerial parts and roots of Turkish liquorice (Glycyrrhiza glabra L.), Int. J. Food Prop. 13(4), 657-671.

[98] İ. Gülçin, E. Kirecci, E. Akkemik, F. Topal and O. Hisar (2010). Antioxidant and antimicrobial activities of an aquatic plant: Duckweed (Lemna minor L.), Turk. J. Biol. 34(2), 175-188.

[99] İ. Gülçin, A.Z. Tel and E. Kirecci (2008). Antioxidant, antimicrobial, antifungal and antiradical activities of Cyclotrichium niveum (Boiss.) Manden and Scheng, Int. J. Food Prop. 11(2), 450-471.

[100] F.M. Abdel Bar (2021) Genus Melaleuca - A review on the phytochemistry and pharmacological activities of the non-volatile components, Rec. Nat. Prod. 15(4), 219-242.

[101] İ. Gülçin, R. Elias, A. Gepdiremen, L. Boyer and E. Köksal (2007). A comparative study on the antioxidant activity of fringe tree (Chionanthus virginicus L.) extracts, Afr. J. Biotechnol. 6(4), 410-418.

[102] İ. Gülçin, M. Elmastas and H.Y. Aboul-Enein (2007). Determination of antioxidant and radical scavenging activity of basil (Ocimum basilicum) assayed by different methodologies. Phytother. Res. 21, 354-361.

[103] A. Musa, K.F. El-Masrry, A.H. El-Ghorab, A. Farouk, H.M. Ali, M.A. Abdelgawad, I.A. Naguib and E.M. Mostafa (2021). Volatile constituents of Cistanche tubulosa and their antioxidant and antimicrobial potentials, Rec. Nat. Prod. 15(4), 301-311.

[104] M. Imran, A. Rauf, T.A. Izneid, M. Nadeem, M.A. Shariati, I.A. Khan, A. Imran, I.E. Orhan, M. Rizwan, M. Atif, T.A. Gondal and M.S. Mubarak (2019). Luteolin, a flavonoid, as an anticancer agent: a review, Biomed. Pharmacother. 112, 108612.

[105] Y.M. Jun, E.H. Kim, J.J. Lim, S.H. Kim, J.D. Lim, D.S. Cheoi, Y.S. Cheoi, C.Y. Yu and M. Chung, 2012. Variation of phenolic compounds contents in cultivated Astragalus membranaceus, Korean J. Med. Crop Sci. 20, 447-453.

[106] A.B. Yildirim, E. Uyar and A.U. Turker (2020). In vitro culture of endemic Astragalus gymnolobus Fischer and comparison of its antibacterial, antioxidant, and phenolic profiles with field grown plants, $J$. Agr. Sci. Tech. 22, 815-828.

[107] Y. Tao, Y.F. Zhang, Y.Y. Cheng and Y. Wang (2013). Rapid screening and identification of alphaglucosidase inhibitors from mulberry leaves using enzyme-immobilized magnetic beads coupled with HPLC/MS and NMR, Biomed. Chromatogr. 27, 148-155.

[108] P. Taslimi, H. Akıncioğlu and I. Gulcin (2017). Synephrine and phenylephrine act as $\alpha$-amylase, $\alpha$ glycosidase, acetylcholinesterase, butyrylcholinesterase and carbonic anhydrase enzymes inhibitor, $J$. Biochem. Mol. Toxicol. 31(11), e21973.

[109] A. Maharramov, M. Kurbanova, P. Taslimi, Y. Demir, A. Safarova, E. Huseyinov, A. Sujayev, S. Alwasel and İ. Gulçin (2021). Synthesis, characterization, crystal structure and bioactivities of novel enamine and pyrrole derivatives endowed with acetylcholinesterase, $\alpha$-glycosidase and human carbonic anhydrase inhibition effects, Org. Commun. 14(2), 144-156.

[110] M. Akdeniz, I. Yener, A. Ertas, M. Firat, B. Resitoglu, N. Hasimi, S.I. Kandemir, M.A. Yilmaz, A.B. Demirkoz, U. Kolak and S. Oksuz (2021). Biological and chemical comparison of natural and cultivated samples of Satureja macrantha C.A. Mey., Rec. Nat. Prod. 15(6), 568-584.

[111] M.T. Riaz, M. Yaqup, Z. Shafiq, Z. Ashraf, M. Khalid, P. Taslimi, R. Taş, B. Tuzun and İ. Gulçin (2021). Synthesis, biological activity and docking calculations of bis-naphthoquinone derivatives from lawsone, Bioorg. Chem. 114, 105069.

[112] U. Atmaca, C. Alp, H. Akıncıoğlu, H.S. Karaman, İ. Gulçin and M. Çelik (2021). Novel hypervalent iodine catalyzed synthesis of $\alpha$-sulfonoxy ketones: Biological activity and molecular docking studies, $J$. Mol. Struct. 1239, 130492.

[113] A. Günsel, P. Taslimi, G. Yaşa Atmaca, A.T. Bilgiçli, H. Pişkin, Y. Ceylan, A. Erdoğmuş, M.N. Yaraşır and İ. Gulçin (2021). Novel potential metabolic enzymes inhibitor, photosensitizer and antibacterial agents based on water-soluble phthalocyanine bearing imidazole derivative, J. Mol. Struct. 1237, 130402. 
LC-HRMS profile of Astragalus brachycalyx extracts and theirbiological activities

[114] K. Pedrood, M. Sherefati, P. Taslimi, M. Mohammadi-Khanaposhtani, M.S. Asgari, S. Hosseini, H. Rastegar, B. Larijani, M. Mahdavi, P. Taslimi, Y. Erden, S. Günay and I. Gulçin (2021). Design, synthesis, characterization, enzymatic inhibition evaluations, and docking study of novel quinazolinone derivatives, Int. J. Biol. Macromol. 170, 1-12.

[115] S. Dasgin, Y. Gok, D. Barut Celepci, P. Taslimi, M. İzmirli, A. Aktaş and I. Gulçin (2021). Synthesis, characterization, crystal structure and bioactivity properties of the benzimidazole-functionalized PEPPSI type of Pd(II)NHC complexes, J. Mol. Struct. 1228, 129442.

[116] S. Bal, Ö. Demirci, A. Aktaş, B. Şen, P. Taslimi, A. Aktaş, Y. Gök, M. Aygün and İ. Gulçin (2021). PEPPSI type Pd(II)NHC complexes bearing chloro-/fluorobenzyl group: Synthesis, characterization, crystal structures, $\alpha$-glycosidase and acetylcholinesterase inhibitory properties, Polyhedron 198, 115060.

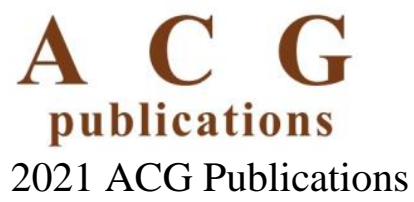

